\title{
A NEMI SZEREPET KONZERVÁLÓ VEZETŐI MAGATARTÁS ÉSZLELT IGAZSÁGOSSÁGA A SZERVEZETI KULTÚRA ÉS AZ ÉSZLELŐ SZEXISTA HOZZÁÁLLÁSÁNAK A FÜGGVÉNYÉBEN
}

\author{
DALLOS ANDREA ${ }^{1}$ - KOVÁCS JUDIT ${ }^{2}$ \\ ${ }^{1}$ DE BTK Pszichológia PhD-hallgató \\ ${ }^{2}$ DE BTK Pszichológiai Intézet, \\ Szociál- és Munkapszichológiai Tanszék \\ E-mail: dallosandi@citromail.hu; kovacs.judit@arts.unideb.hu
}

Beérkezett: 2014. október 10. - Elfogadva: 2014. december 20.

\begin{abstract}
A tanulmányban bemutatott vizsgálat célja, hogy feltárja a segitségnyújtás nemiszerep-elvárásokkal összhangban lévő vagy ellentétes megjelenésének, vagy elmaradásának, valamint az erre a megnyilvánulásra adott vezetői reakciónak az észlelt helyességét. A személy nemének, a segitségnyújtás megjelenésének és a helyzetre adott vezetöi válasznak a manipulációján (jutalmazó/büntetö, illetve semleges válasz) túl a helyzet kontextusaként szolgáló szervezeti kultúrának, illetve a szexista nézetek válaszadó általi támogatottságának a hatását is figyelembe vettük.

Kérdöives vizsgálatunkban 310 nö és 65 férfi vett részt. A válaszadók egy rövid munkahelyi szituációt olvashattak, melyben manipuláltuk az elözőekben megnevezett tényezőket. Ezt közetöen a kitöltők megitélték a szereplő és a vezetö viselkedésének észlelt helyességét, továbbá kitöltötték az ambivalens szexizmust mérő skálát.

Eredményeink szerint a válaszadók a segítségnyújtást annak elmulasztásánál egyöntetüen helyesebbnek látták, megitéléseikre a kezelt független változók nem hatottak. A vezetö semleges válasza esetén a versengö/maszkulin szervezeti kultúráról olvasók, valamint a magasabb szexizmussal jellemezhetö válaszadók igazságosabbnak észlelték a férfi szereplö irányába mutatott semleges vezetöi reakciót, míg a nöi szereplövel szembeni semlegességet kevésbé helyeselték, ezzel elfogadva a hagyományos nemi szerepek konzerválását. Ezzel szemben a vezetö büntetö/jutalmazó reakciója esetén a kevésbé szexista válaszadók, valamint a támogatólfeminin szervezeti kultúráról olvasók, a nemi szerepeket megfordító vezetői viselkedést helyeselték, a nöi szereplö megjutalmazását, valamint a férfi szereplö megbüntetését.
\end{abstract}

Kulcsszavak: nemi szerepek, nemi szerep elvárások, segítségnyújtás, igazságosság, szexizmus 


\section{BEVEZETŐ}

A nők munkaerő-piaci helyzetének javulása ellenére a nőkkel szembeni nemi diszkrimináció a munkahelyen továbbra is problémát jelent, továbbra is jelen van a nemi szegregáció, a nők alacsonyabb fizetése, valamint a nők alulreprezentáltsága a felsőbb vezetői szinteken (NGUYEN, 2005).

A vizsgálatunk célja annak feltárása volt, hogy az egyik alapvető sztereotipikusan nemhez kapcsolt szervezeti viselkedés, a segítségnyújtás esetében hogyan ítélik meg az emberek a nemi elvárásoknak megfelelő, illetve az azokkal ellentétes dolgozói viselkedéseket, mennyire vélik a vezetőnek a segítésre adott jutalmazó, büntető vagy éppen semleges válaszát megfelelőnek. Nemcsak a segítséget nyújtó vagy nem nyújtó személy értékelésével kapcsolatban vártuk, hogy abban a hagyományos nemi szerepek nézőpontja - releváns háttértényezők által is befolyásolt módon - érvényesül, de a segítségnyújtásra vagy annak elmaradására reagáló főnöki viselkedés igazságosságának a megítélésében is.

Ezeknek a kérdéseknek a feltárását több szempontból is fontosnak tartottuk. Ha a nők észlelik a velük szemben jelentkező eltérő elvárásokat és a viselkedésük eltérő értékelését, akkor ezt nemi diszkriminációként élhetik meg, melynek nemcsak az egyéni szinten (például önértékelés csökkenése (DION, 1975); munkahelyváltás (NEUMARK és MCLENNAN, 1995), hanem a szervezeti szinten is negatív következményei lehetnek. A teljesítményértékelésben eltérő módon figyelembe vett viselkedések az igazságtalanság érzetét kelthetik az egyénben, ami az elégedettség és a szervezet iránti bizalom csökkenéséhez vezethet.

Míg a korábbi kutatások jellemzően a nemekre vonatkozó eltérő elvárásokkal és a teljesítményértékelésekkel foglalkoztak, addig ez a kutatás az eltérő elvárások és eltérő teljesítményértékelés megitélésével is foglalkozik, ezzel mintegy kiszélesítve a szereplők körét a sztereotípiák vizsgálatában. Véleményünk szerint ezzel az eljárással a nemi sztereotípiák működéséről teljesebb képet alakíthatunk ki.

\section{Nemi diszkrimináció a munkahelyen}

Egy személlyel találkozva a nem az első észlelt tényezők között van. Ennek a csoporttagságnak az észlelése automatikusan aktiválja bennünk a nemekkel kapcsolatos sztereotípiáinkat, és ezek az ismeretek és feltevések gyakran diszkriminációhoz vezethetnek. Bár a nemi diszkrimináció áldozatai nők és férfiak egyaránt lehetnek, általában jellemzőbb a nők leértékelése egy ugyanolyan képzettségű férfival szemben, és a férfiak számára kedvező előfeltevések alkalmazása (DAVISON és BURKE, 2000).

A munka világában a nőkkel szemben a diszkrimináció több ponton is megtörténhet: a toborzás során a hirdetések megfogalmazásában (GAUCHER, FRIESEN és KAY, 2011), a kiválasztás során (DIPBOYE, ARVEY és TERPSTRA, 1977), de a teljesítményértékelés során is. A nők munkahelyi sikereit a megítélők hajlamosak a szerencsének és más helyzeti faktoroknak tulajdonítani, míg a férfiak sikereinek 
hátterében a megfelelő képességeket feltételezik (DEAUX és EMSWILLER, 1974; HEILMAN és Guzzo, 1978). Részben ezek a teljesítménnyel kapcsolatos feltételezések nehezítik meg a nők előrelépési lehetőségeit, másrészt pedig azok az elképzelések, amelyek szerint a nők nem rendelkeznek a vezető pozíciók hatékony betöltéséhez szükséges képességekkel (NGUYEN, 2005).

E megkülönböztetésekhez sok esetben a nemekkel kapcsolatos sztereotípiákból fakadó eltérő elvárások vezetnek, amelyek egyrészt tulajdonságokra (leíró/deskriptív sztereotípia), másrészt a viselkedésre (előíró/preskriptív sztereotípia) vonatkoznak (HOFFMAN és Hurst, 1990). Például azt várjuk, hogy a nők kapcsolatorientáltak és segítőkészek. A nemekkel szemben élő eltérő nemi sztereotípiák miatt úgy észlelhetjük, hogy bizonyos munkakörök, feladatok követelményei nincsenek összhangban az adott nem jellemzőivel (HEILMAN, 2001, 2012).

A nemi diszkrimináció észlelésének negatív következményei lehetnek egyéni és szervezeti szinten egyaránt. A nemi alapú megkülönböztetés észlelése rosszabb pszichológiai jólléthez, alacsonyabb önértékeléshez (DION, 1975; SCHмiTt, BRANSCOMBE és POSTMES, 2003), valamint a munkahely elhagyásához vezethet (Neumark és MCLennan, 1995). A szervezet számára a csökkenő teljesítmény, a gyakoribb hiányzások és a munkával való elégedetlenség miatt lehet anyagilag veszteséges (PRYOR, 1995). Egy nevesített diszkriminációs eset következtében mindezeken túl a szervezet reputációján is folt eshet.

\section{Segitségnyújtás mint a nöi nemi sztereotípia része}

A nemi sztereotípiákból következő elvárások miatt a nőket a munkahelyükön is kedveseknek, gondoskodóaknak, a férfiakat pedig ambiciózusoknak és irányítónak várjuk (Heilman, 2001, 2012; Prentice és Carranza, 2002). A szervezeti magatartás terén is eltérő elvárások élhetnek a nemekkel szemben: a segítés és udvariasság általában inkább a nőktől elvárt, a sportszerűség és a polgári erény pedig inkább a férfiak „reszortja” (KIDDER és MCLEAN PARKS, 2001).

A nemiszerep-elvárások miatt a nőktől általában tehát nagyobb mértékben elvárt a segítő viselkedés, így az emberek a nők általi segítségnyújtást sokkal inkább észlelik a női szerep részének. HeILMAN és CHEN (2005) kutatássorozatukban arra voltak kíváncsiak, hogy az altruista magatartás megjelenése vagy elmaradása milyen hatást gyakorol a nők és a férfiak teljesítményének, kompetensségének, jutalmakra és előléptetésre való érdemességének és interperszonális előzékenységének a megítélésére. Vizsgálati személyeik egy női vagy egy férfi alkalmazott teljesítményértékelését olvashatták, amelyben egy rövid munkahelyi, segítségnyújtási szituáció leírása is megjelent. Ebben a történetben vagy az szerepelt, hogy az értékelt alkalmazott segített, vagy pedig az, hogy nem. Azt figyelték meg, hogy amikor a segítségnyújtásra sor került, a női szereplő kevésbé esett pozitív megítélés alá (a teljesítmény, előléptetés és jutalmakra való érdemesség tekintetében), mint a férfi. A szerzőpáros tehát igazolta, hogy a nők számára az altruista szervezeti magatartás sokkal inkább kötelességként, mint opcióként jelenik meg (HEILMAN és CHEN, 2005). 


\section{Szervezeti kultúra és segítségnyújtás}

A szervezetek egyik meghatározó jellemzője a szervezeti kultúra, amely SCHEIN (1984) modellje szerint a szervezet tagjai által osztott, alapvető értékekből és hiedelmekből szerveződő normarendszer, amelyet az adott csoport fejlesztett ki a problémákkal való megküzdésre, és eléggé hatékonynak bizonyult ahhoz, hogy validnak tekintsék és továbbadják a szervezet új tagjai számára. A szervezeti kultúra ennek megfelelően meghatározza azt, ahogy a tagok éreznek, vélekednek és viselkednek (SCHEIN, 1984). Ez a szervezeti normarendszer közvetíti a tagoknak, hogy mely viselkedések fontosak a szervezet számára, hogy hogyan szabad viselkedniük és mit kell tenniük a szervezet érdekében (VEIGA, LUBATKIn, CALORI és VERY, 2000).

Vannak olyan szervezetek (versengő, maszkulin szervezetek), ahol a versengés, az individualizmus, a függetlenség és a feladatorientáltság a magasra értékelt. Ezekben a szervezetekben jellemzően a hagyományos nemiszerep-elvárások jelennek meg: a férfiaknak sikeres kenyérkeresőknek kell lenniük, ők töltik be a vezetői pozíciókat, a nőknek pedig elsődlegesen a családról kell gondoskodniuk (Maier, 1999; idézi: Catanzaro, Moore és Marshall, 2010). Ezzel szemben vannak olyan kultúrájú szervezetek is (támogató, feminin szervezetek), ahol az együttműködés, az egyenlőség és a személyközi kapcsolatok értékelése jellemző, így szorgalmazzák a segítségnyújtás megjelenését a munkatársak között, valamint a nemekkel szemben hasonló szerepelvárások jelentkeznek (MAIER, 1999; idézi: Catanzaro, MoOre és Marshall, 2010; SOMEch és Drach-ZAhavy, 2004).

\section{A segitségnyújtás értékelésének észlelt igazságossága}

Annak észlelete, hogy az egyénnel szemben a munkahelyen más elvárások élnek, és viselkedését máshogy ítélik meg pusztán a neme miatt, az igazságtalanság érzetét keltheti. Az igazságosság egy arra vonatkozó szubjektív észlelet, hogy a kimenetek/eredmények, amelyben az egyén részesült, igazságosak-e, valamint hogy maga a folyamat, amely az eredményekhez vezetett fair volt-e (COLQUITT, CONLON, Wesson, PORTER és NG, 2001; KOVÁCS, 2014). Az emberek többségének igazságosságérzete megkívánja, hogy még a segítségnyújtást is beleszámítsák a teljesítményértékelésbe (JOHNSON, HOLLADAY és QuiNONES, 2009).

\section{Szexizmus}

Mivel a kutatásunk középpontjában a nemi elvárásoknak megfelelő vagy azokkal ellentétes viselkedés észlelete áll, így fontosnak tartottuk a szexizmus mint lehetséges befolyásoló tényező bevonását a vizsgálatba. A szexizmus a nemekkel kapcsolatos attitűdöket jelenti, melyek nem kizárólagosan negatívak; a szexizmus a nemekkel szemben élő pozitív és negatív viszonyulásokat egyaránt magában foglalja (Fernandez, Castro és Lorenzo, 2004; Glick és Fiske, 2006). Mind a ne- 
mekkel kapcsolatos ellenséges, mind pedig a jóindulatú attitűdök magukban hordozzák a hagyományos nemi szerepek elfogadását, és hozzájárulnak a nemi szerepek hagyományos felosztásának fennmaradásához (GLICK és Fiske, 1997). Az emberek eltérnek annak tekintetében, hogy mennyire vallják ezeket a nemekkel kapcsolatos ellenséges és jóindulatú attitűdöket, és elfogadásuk mértéke egyaránt befolyásolja az észleleteiket és viselkedésüket is (például RUSSEL és TRIGG, 2004).

\section{VIZSGÁLAT}

\section{Kérdésfelvetés, hipotézisek}

A kutatásunk kiinduló pontját a HEILMAN és CHEN (2005) által végzett vizsgálat jelentette, ugyanakkor kérdéseink némileg eltértek az övéiktől. HEILMAN és CHEN (2005) elsődlegesen arra keresték a választ, hogy a segítő szervezeti magatartás megjelenése vagy elmaradása milyen hatást gyakorol egy nő és egy férfi megítélésére. A mi vizsgálatunknak is célja volt többek között, hogy a segítségnyújtást mutató vagy nem mutató személyek megítélését vizsgáljuk, de esetünkben a válaszadók nem következtetéseket vontak le ennek az információnak az alapján, hanem magát az alapviselkedést értékelték helyesnek vagy helytelennek. Ezzel mintegy ellenőriztük, hogy a levont következtetések mögött, a deklarált nézetek szintjén vajon kitapintható-e az a nemi elfogultságokkal teli konszenzus, amelyből a HEILMAN és CHEN (2005) által feltárt következtetések logikusan adódtak.

További kérdésként felmerült az is, hogy az emberek mennyire értékelik a vezető ilyen helyzetre adott jutalmazó/büntető vagy semleges viselkedését igazságosnak, hiszen a vezető értékelése lehetőséget nyújt arra, hogy a hagyományos nemiszerep-elvárások kerülő úton nyerjenek helyeslést, melyeknek a közvetlen hangoztatását ma már az emberek talán nem is találnák politikailag korrektnek.

A kutatásunkban igyekeztünk továbbá olyan tényezőket figyelembe venni, amelyek számottevően befolyásolhatják a vizsgálati kérdésünkre adott válaszokat, így a válaszadóknak a szexista nézetekkel való egyetértését és a segítségnyújtás kontextusaként szolgáló szervezeti kultúrát is bevontuk a vizsgálatba.

\section{Hipotéziseink}

(H1): A nemi szerepnek megfelelö viselkedés elönyben részesitése, helyeslése:

H1a: A női nemi szerepnek megfelelő segítségnyújtást a személyek jobban helyeslik női segítő esetében, mint férfi segítőében, a segítségnyújtás elmaradását pedig jobban helytelenítik, ha azt nő mutatta, mint akkor, ha férfi.

$\boldsymbol{H 1 b}$ : A $H 1 a$ hipotézisben feltételezett tendenciát erősíti, ha a válaszadó nagyobb mértékben egyért a szexista nézeteket kifejező állításokkal.

H1c: A H1a hipotézisben feltételezett tendenciát erősítheti, ha a segítségnyújtás kontextusául szolgáló szervezeti kultúra inkább versengő, maszkulin, ugyanis a versengő, maszkulin szervezeti kultúra inkább hordozza a hagyományos nemiszerep-elvárásokat. 
(H2): A nemi szerepek megerösitésére irányuló fönöki magatartás igazságosnak látása:

$\boldsymbol{H} 2 \boldsymbol{a}$ : A segítségnyújtásra, illetve annak elmaradására akár semlegesen, akár jutalmazó/büntető módon reagál a vezető, a megítélők nagyobb mértékben tesznek a helyes és helytelen között különbséget a nők, mint férfiak esetén. Továbbá nők esetében helyesebbnek ítélik a nemi sztereotípiák szerinti viselkedés nyílt támogatását a hallgatólagoshoz képest.

$\boldsymbol{H} 2 \boldsymbol{b}$ : A $H 2 a$ hipotézisben megfogalmazott feltételezést tovább erősíti, ha a válaszadóra a nemi sztereotípiák elfogadása nagyobb mértékben jellemző.

$\boldsymbol{H} 2 \boldsymbol{c}$ : A $H 2 a$ hipotézisben feltételezett tendenciát tovább erősíti, ha a segítségnyújtás kontextusául a versengő, maszkulin kultúra szolgált.

\section{Alanyok és eljárás}

A kérdőívek felvétele részben egy online felületen, részben pedig papíralapon zajlott. Az adatszolgáltatás önkéntes alapon, névtelenül történt. A személyek közötti összehasonlítást alkalmazó vizsgálatban 375 személy, 310 nő és 65 férfi adatait vetettük analízis alá. A vizsgálati mintánk egy részét egyetemisták, másik részét többéves munkatapasztalattal rendelkező, jellemzően közepesen iskolázott személyek alkották. Mivel a szakirodalom szerint az életkorral nő a nőkkel szembeni ellenséges nézetek támogatása, különösen a nők körében (FERNANDEZ, CASTRO és LORENZO, 2004), így a vizsgálati személyek átlagos életkora $(M=27,09)$ mentén két életkori csoportot képeztünk, és összehasonlítottuk a két csoport Ambivalens Szexizmus Skálán (GLICK és FisKe, 1996) elért átlagait. A két csoport között nem jelentkezett szignifikáns különbség $(U=14915 ; p=0,241)$, így a további analízisekbe mindkét életkori csoport adatait bevontuk. Így a vizsgálati személyek átlagos életkora 27,09 év, szórása 7,74 volt. A vizsgálati személyek a nemre és korra vonatkozó kérdéseket követően egy történetet olvashattak. Az olvasott történeteket négy tényező mentén manipuláltuk, mind a négy esetében 2-2 lehetőséggel számolva. A független változóknak megfelelően 16 (vagyis $2^{4}$ ) feltétel jött tehát létre, amelyekbe a kitöltők az online felületbe beépített randomizáló eljárás alapján, illetve a papíralapú kérdőívek véletlenszerü kiosztásával kerültek be.

A szituáció elolvasása után a személyek a szereplő, valamint a főnök viselkedésének megítélésére vonatkozó állításokat olvashattak, majd egy szexista nézeteiket vizsgáló skálát töltöttek ki.

\section{Eszközök}

\section{Független változók manipulálása}

A vizsgálati személyek a kérdőív elején tehát egy rövid munkahelyi szituációt olvashattak. Ez a történet vagy egy iskolában, vagy pedig egy bankban játszódott. Azért ezt a két helyszínt választottuk, ugyanis úgy gondoltuk, hogy az iskola tipikusan egy támogató, femininebb környezet, míg a pénzügyi világ (a bank) inkább 
egy versengő, férfiak által uralt terület. A vázolt szituációban a főszereplő (Ágnes vagy Gábor) segítségét kérte az egyik kolléga. A főszereplő ebben a helyzetben vagy segitett a kollégájának, vagy pedig megtagadta a segitségnyújtást, amire a főnök vagy semlegesen („örömmel állapította meg, hogy elrendeződött a probléma”) reagált, vagy pedig jutalommal/büntetéssel („,segítségét egy plusz szabadnappal jutalmazta meg") (1. melléklet).

\section{A szereplő viselkedésének megitélése}

A szereplő viselkedésének megítélésére a kitöltők három, a szereplő viselkedésének helyességére vonatkozó állítást olvashattak (például „Ágnes a helyzetnek megfelelően járt el”), amelyekkel egyetértésüket egy 7 fokú skálán jelezhették (2. melléklet). A skála megbízhatósági mutatója (Cronbach- $\alpha=0,82)$ alapján a 3 itemet összevontuk, és az így képzett átlagot használtuk a továbbiak során.

\section{A fönök viselkedésének megitélése}

A vizsgálati személyek a főnök viselkedésének megítélésére vonatkozóan szintén 3, a főnök magatartásának helyességére, igazságosságára vonatkozó állítást olvashattak (például „A főnök fair módon járt el”), melyekkel egyetértésüket szintén 7 fokú skálán jelezhették (3. melléklet). A megbízhatósági mutató alapján (Cronbach- $\alpha=0,93)$ az itemek összevont átlagával dolgoztunk tovább.

\section{Ambivalens Szexizmus Skála (GLICK és FISKE, 1996)}

A GLICK és Fiske (1996; magyarul: GLICK és FISKE, 2006) által kialakított skála a szexizmus két, egymással korreláló komponensét vizsgálja. Az egyik a nőkkel szembeni Ellenséges Szexizmus (Hostile Sexism-HS), a másik pedig a nőkkel szembeni szubjektívan pozitív viszonyulás: a Jóindulatú Szexizmus (Benevolent Sexism-BS). A kérdőív 22 itemből áll, amelyek mellett egy 6 fokú skálán $(0=$ egyáltalán nem ért egyet, $5=$ teljes mértékben egyetért) kell jelezni a velük való egyetértést. A vizsgálatok alapján a skála belső megbízhatósága ( 0,83 és 0,92 közötti Cronbach- $\alpha$-k; GLICK és Fiske, 1996) megfelelő és a jelen vizsgálatban is hasonló eredmény jelentkezett (Cronbach- $\alpha$ : 0,88).

A kérdőív két alskálája 11-11 itemet foglal magában (jóindulatú állítás, például „Bármit is visz véghez egy férfi, nem lehet teljes az élete, ha nem tudhatja magáénak egy nő szeretetét”, míg egy ellenséges állítás például „Sok nő az egyenlőség leplébe bújtatva különböző kedvezményeket kér, például a foglalkoztatásban, hogy előnyhöz jusson a férfiakkal szemben”). Jelen vizsgálatban a jóindulatú (Cronbach- $\alpha=0,82)$ és az ellenséges alskála (Cronbach- $\alpha=0,87)$ megbízhatósága is jónak mondható. 


\section{EREDMÉNYEK}

A nemi szerepnek megfelelö viselkedés elönyben részesitésére vonatkozó hipotézisek $(H 1 a-c)$ vizsgálata

Hipotéziseink első csoportját $(\mathrm{H} 1 \mathrm{a}-\mathrm{c})$ varianciaanalízissel vizsgálatuk, amelyben függő változóként a szereplő viselkedésének megítélése, független változókként a munkahelyi kultúra, a szereplő neme, a segítés megtörténte valamint az ambivalens szexizmus szolgáltak. A szereplő viselkedésének megítélésére kizárólag a segítés ténye fejtett ki szignifikáns fóhatást $\left(F_{\mathrm{SEGíTÉs}}[1,374]=15,046 ; p=0,000\right)$ : a segítés megjelenése esetén helyesebbnek látták a szereplő viselkedését, mint abban az esetben, ha a segítségnyújtás elmaradt. Ugyanakkor fontos megjegyezni, hogy ha a férfiakon és a nőkön bontva végezzük el ezt az analízist, akkor a férfiak a segítségnyújtást nem helyeslik jobban annak elmaradásánál $\left(F_{\text {SEGíTés }}[1,64]=\right.$ $0,011 ; p=0,918)$. Ezek alapján tehát a Hla-c hipotéziseink nem teljesültek, vagyis válaszadóink nem a nemi sztereotípiák mentén ítélték még a történet szereplőjének viselkedését.

\section{A nemi szerepek megerösitésére irányuló fönöki magatartás igazságosnak látására vonatkozó hipotézisek $(\mathrm{H} 2 a-c)$ vizsgálata}

Hipotéziseink második csoportját szintén varianciaanalízissel vizsgáltuk, melybe függő változóként a főnök viselkedésének megítélését, független változókként a szereplő nemét, a segítés megtörténtét, a főnök helyzetre adott reakcióját és a szervezeti kultúrát, valamint az ambivalens szexizmust vontuk be.

Az analízis során három interaktív hatás jelentkezett. A segítés tényének, valamint a fönök reakciójának szignifikáns interaktív hatása van a főnök viselkedésének megítélésére $\left(F_{\text {SEGítés } \times \text { FÖNÖK REAKCIÓJA }}[3,374]=8,271 ; p=0,000\right)$. Segítségnyújtás esetén helyesebbnek ítélték a jutalmazást, mint a semleges választ; a segítségnyújtás elmaradása esetén pedig helyesebbnek ítélték a semleges választ, mint a büntetőt. Ez az összefüggés hipotézisvizsgálatunk szempontjából nem különösebben releváns, hiszen a segítségnyújtó neme nem szerepel benne.

Annál inkább releváns a nemi szerepet konzerváló reakció helyeslésének a feltételezése szempontjából, hogy a nagymértékben szexista személyek a semleges reakcióhoz állnak hozzá rájuk jellemző (konzerváló) módon, a kismértékben szexisták pedig a jutalmazó/büntető reakcióhoz állnak hozzá szintén rájuk jellemző (megfordító) módon $\left(F_{\text {SZNEME } \times \text { SEGÍTÉs } \times \text { FÖNÖKREAKCIÓJA } \times \text { ASI }}[8,374]=1,965 ; p=0,05\right)$.

Ahogy azt a semleges főnöki reakció megítélését mutató 1 . és 2. ábrákon láthatjuk, a nem segítést természetesnek venni helytelenebb, mint ugyanezt tenni a segítéssel. Ez hasonló a két nem vonatkozásában, de erősebbnek látszik a nők esetében, vagyis e semleges hozzáállásra a válaszadók jellemzően nemi szerepet konzerváló módon reagáltak, különösen a magasabb szexizmussal jellemezhető személyek. Számukra egy férfi segítségnyújtását természetesnek venni a tendenciát 
megközelítő módon helytelenebb, mint egy nő segítségnyújtását természetesnek venni (post hoc LSD-próba $p=0,155$ ).

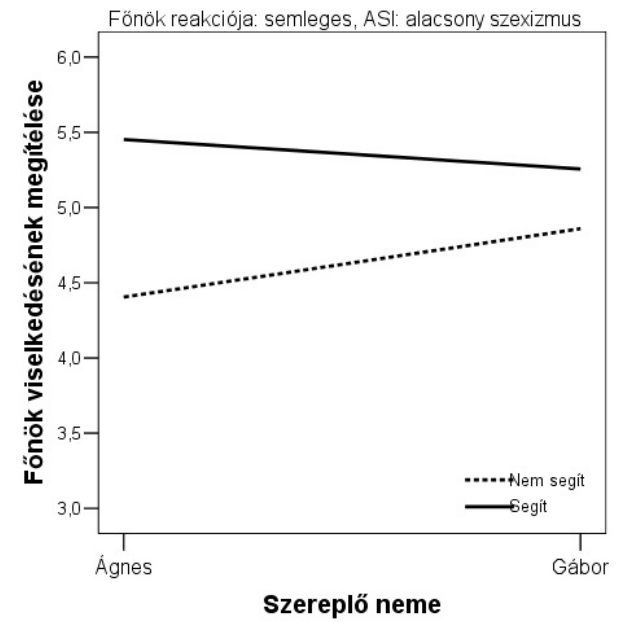

1. ábra. A szereplő nemének és főnök megítélésének kapcsolata a fónök semleges reakciója és a válaszadó alacsony szexizmusa esetén

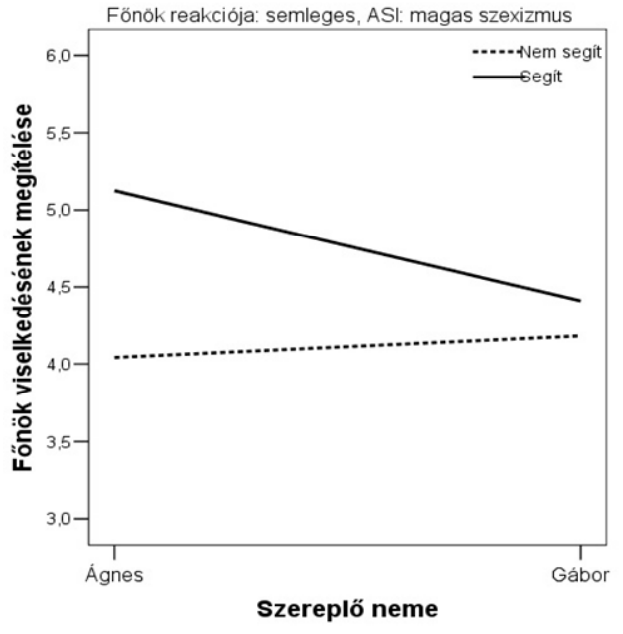

2. ábra. A szereplő nemének és főnök megítélésének kapcsolata a főnök semleges reakciója és a válaszadó magas szexizmusa esetén

Viszont ha a főnök büntetéssel vagy jutalmazással reagál a helyzetre, akkor inkább a nemiszerep-megfordító hozzáállás jelentkezik, különösen a kevésbé szexisták részéről. A kevésbé szexista vizsgálati személyek (3. ábra) helyesebbnek ítélik Gábor elmarasztalását, mint Ágnes megbüntetését (post hoc LSD-próba, $p=0,012$ ). A magas szexizmussal jellemezhető válaszadók (4. ábra) körében nem jelentkezik ilyen „nemiszerep-megfordító” viszonyulás: nagyjából ugyanúgy ítélik meg a főnök viselkedésének helyességét a szereplő nemétől függetlenül (segítés megjelenésekor LSD-próba $p=0,71$; segítés elmaradásakor $p=0,729$ ).

Ezek alapján azt mondhatjuk, hogy a semleges vezetői reakció feltételben megjelent a H2a hipotézisben feltételezettnek megfelelő tendencia: a válaszadók nagyobb különbséget tettek a vezető viselkedésének észlelt helyességében, amikor nő volt a szereplő, mint amikor férfi. Ugyanakkor ez a különbség már nem figyelhető meg a főnök jutalmazó/büntető reakciójakor. 


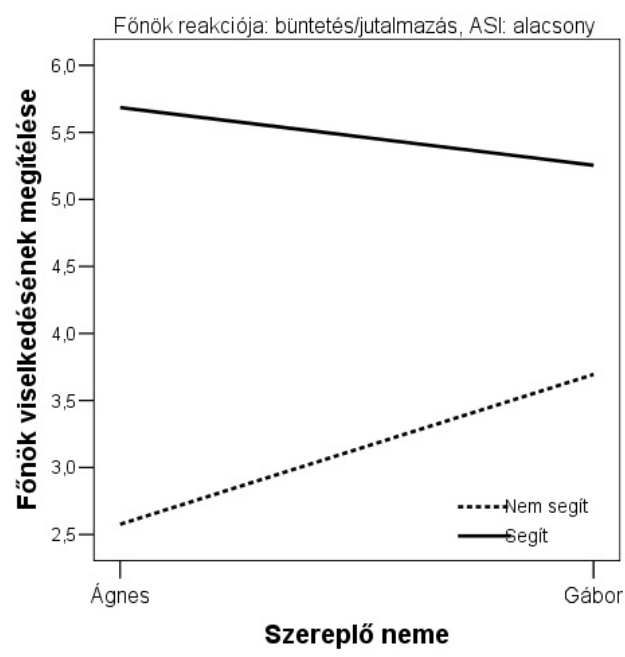

3. ábra. A szereplő nemének és főnök megítélésének kapcsolata a főnök büntető/jutalmazó reakciója és a válaszadó alacsony szexizmusa esetén

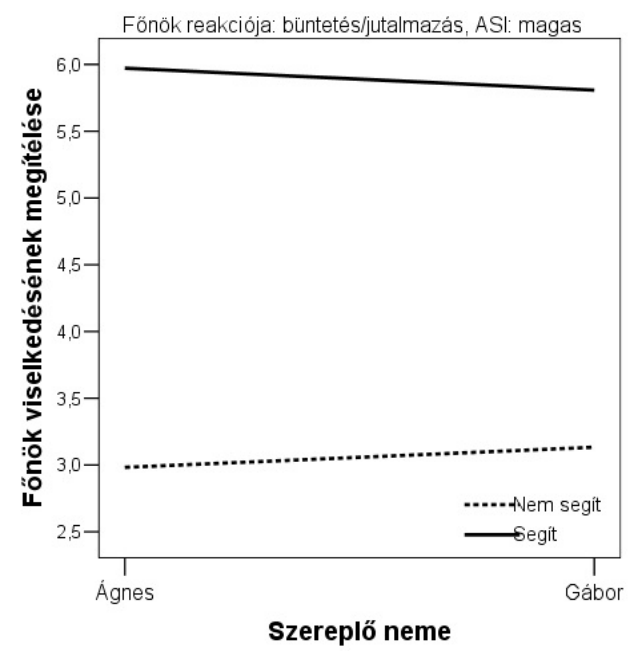

4. ábra. A szereplő nemének és főnök megítélésének kapcsolata a fönök büntető/jutalmazó reakciója és a válaszadó magas szexizmusa esetén

A hipotéziseink szempontjából egy másik tendenciaszintű interakció is releváns, amely a munkahelyi kultúra, a szereplő neme, a segítés megtörténte és a főnök helyzetre adott reakciója között jelentkezett $(F$ MUNKAH $\times$ SzNEME $\times$ SEGítés $\times$ FŐNÖKREAKCIÓJA $[12,374]=1,674 ; p=0,071)$. Az interakció jelentése szerint a főnök

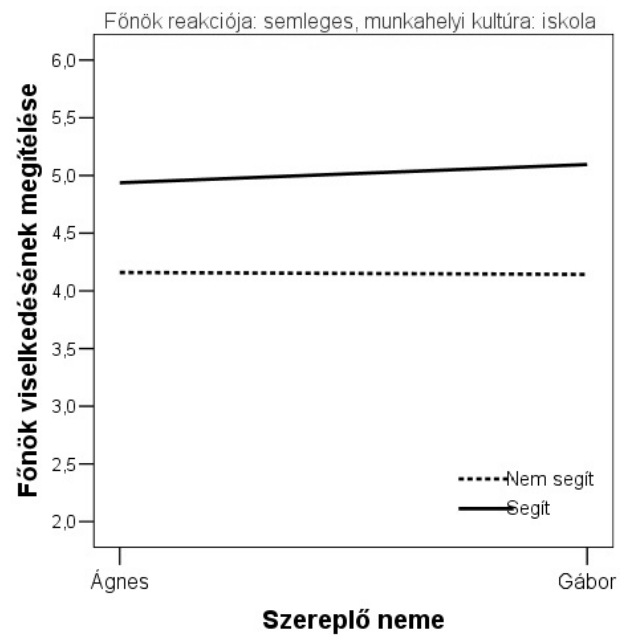

5. ábra. A szereplő nemének és főnök megítélésének kapcsolata a fönök semleges reakciója és iskolai munkahelyi kultúránál

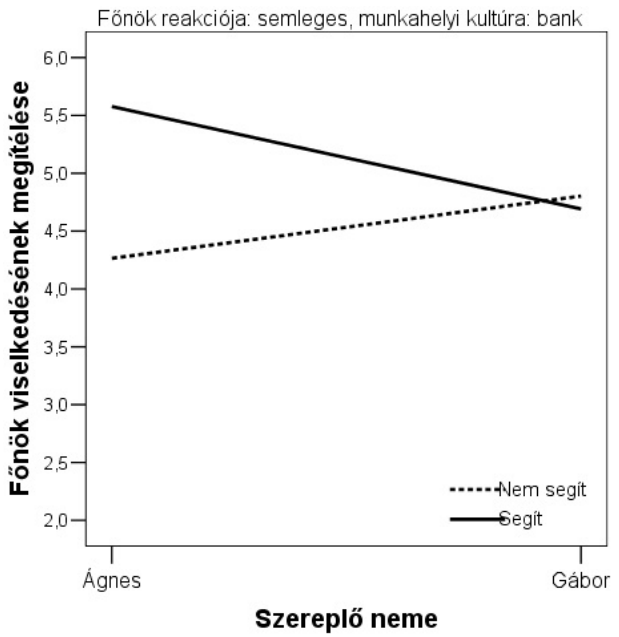

6. ábra. A szereplő nemének és főnök megítélésének kapcsolata a főnök semleges reakciója és banki munkahelyi kultúránál 
semleges reakciója esetén a bankban játszódó történetre a válaszadók inkább nemi szerepeket konzerváló módon és a jutalmazó/büntető reakciója esetén pedig az iskolai történetre inkább nemiszerep-megfordító módon reagálnak.

Mint ahogyan azt az 5. ábrán is láthatjuk, az iskolai körülmények között nagyjából ugyanolyan helyesnek ítélik meg a főnök viselkedését Ágnesnél és Gábornál is (segítés megjelenésekor LSD-próba $p=0,763$, segítés elmaradásakor $p=$ 0,974). Ellenben, a banki kultúra feltételben különbségek jelentkeznek. A segítségnyújtásra adott semleges választ tendencia szinten megfelelőbbnek ítélik női, mint férfi segítő esetében (LSD-próba $p=0,066$ ); a segítés elmaradására adott semleges reakciót azonban nem helyeslik szignifikáns szinten erősebben Gáborra vonatkozóan (LSD-próba $p=0,297)$ (7. ábra).

A szervezeti kultúra befolyása a történet megítélésére akkor is megjelenik, ha a főnök jutalmazással vagy büntetéssel reagált a szituációra (7. és 8. ábrák), csakhogy akkor az iskolai történetre reagálnak a válaszadók a szereplő nemének a függvényében, nemiszerep-megfordító módon.

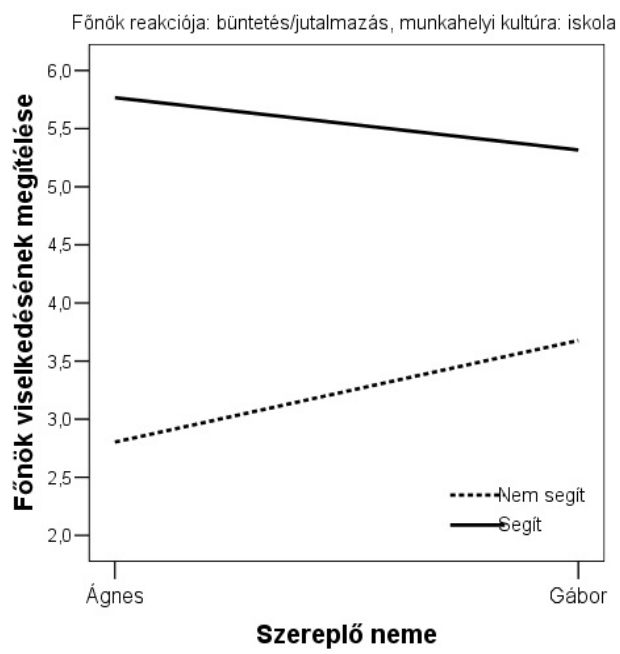

7. ábra. A szereplő nemének és főnök megítélésének kapcsolata a főnök büntető/jutalmazó reakciója és iskolai munkahelyi kultúránál

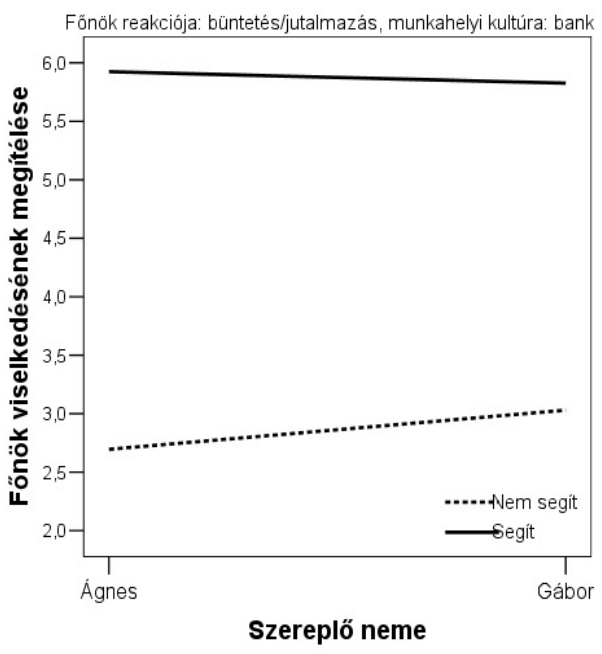

8. ábra. A szereplő nemének és főnök megítélésének kapcsolata a főnök büntető/jutalmazó reakciója és banki munkahelyi kultúránál

Segítségnyújtásnál ugyan nem helyeslik jobban Ágnes jutalmazását, mint Gáborét, sem egyik, sem másik szervezeti kultúrában (LSD-próba iskolai $p=0,363$; banki kultúránál $p=0,833$ ), a nem segítés feltétele mellett viszont az iskolában megfelelőbb főnöki reakciónak tartják Gábor megbüntetését, mint Ágnes megbüntetését (LSD-próba iskolai $p=0,046$; banki helyzetben $p=0,431$ ). 


\section{MEGVITATÁS}

A nemi szerepeket konzerváló hozzáállással kapcsolatos hipotéziseinkben megfogalmazott elvárások csak részben teljesültek. A segítségnyújtó vagy segítségnyújtást elmulasztó személy megítélésében a válaszadók nem nemi alapon ítélték meg a szereplő magatartásának megfelelőségét, kizárólag a segítés megjelenése mentén értékeltek. Viszont a fönöki reakciók megítélésével kapcsolatban mutatkoztak elvárásaink szerinti összefüggések. Bizonyos feltételek mellett megjelent az igény a nemi szerepek konzerválására (a semleges vezetői reakció esetén az erősebben szexistáknál, illetve a versengő/maszkulin szervezeti kultúrában (,a férfiak segítségadása nem természetes" értelemben). Más feltételek mellett pedig megjelent az igény a nemi szerepek megfordítására. Így történt a fönök jutalmazó/büntető reakciója esetén a kevésbé szexista személyeknél, illetve azoknál, akik a támogató/feminin kontextusról olvastak („Rendben van, ha a nem segítés miatt egy férfit megbüntetnek" értelemben). Eredményeinkkel kapcsolatban fontos megjegyeznünk, hogy a női válaszadók nagy és a férfi válaszadók kis száma miatt a leírt öszszefüggések és tendenciák elsődlegesen a nők segítségnyújtási helyzethez való viszonyulását tükrözik.

Az Ambivalens Szexizmus elmélete alapján a nőkkel szembeni ellenséges és jóindulatú szexizmus egy integrált rendszert alkotnak, amely igazolja és fenntartja a férfiak magasabb státuszát és hatalmát a társadalomban. Az ellenséges, de különösen a jóindulatú szexizmus is hozzájárul a nemek közötti egyenlőtlenségek fennmaradásához. A jóindulatú szexizmus azáltal, hogy igazolja az azokkal a nőkkel szembeni negatív viszonyulást, akik kilépnek a hagyományos nemi szerepek korlátai közül, hozzájárul a jelenlegi rendszer fennmaradásához (GLICK és FISKE, 1996). Így egy vezető nemi szerepeket megerősítő viselkedésének helyeslése mögött is a fennálló rendszer igazolására való igény állhat: a válaszadók elfogadhatónak, sőt igazságosnak látják azt, ha a vezető a hagyományos nemi szerepekkel összhangban cselekszik. Kutatásunkban ez inkább jellemezőnek bizonyult a szexista nézeteket nagyobb mértékben elfogadókra. Figyelemre méltó, hogy a nemi szerepek konzerválásának helyeslése csak azokban a helyzetekben figyelhető meg, amikor a vezető semlegesen reagált. Hogy miért csak ebben az esetben jelenik meg a nemi szerep konzerválásának helyeslése, annak hátterében talán az állhat, hogy a rendszerigazolás racionalizáló elhárító mechanizmusa (JOST, PELHAM és CARVALLO, 2002) nagyobb teret kaphat az automatikus müködések szintjén szemben a tudatos véleményformálással. A semleges reakció feltétel ugyanis elaltathatta az emberek figyelmét, hiszen a főnök ebben a helyzetben nem tett semmi konkrétat. Ezzel szemben, amikor a főnök aktív módon (jutalommal/büntetéssel) reagált a helyzetre, indokot adott a nemi szerepek közötti különbségek megőrzésének helytelenítésére. Erre az indokra inkább felfigyeltek azok, akik érzékenyek voltak a különbségek megőrzésének helytelenítésére, tehát a kevésbé szexisták, illetve azok, akiknek a történet az iskolai környezetben helyezte el a segítés problematikát.

Egy másik elgondolkodtató eredménye a kutatásunknak az a megfigyelés, hogy a személyek viselkedésének megítélésénél nem jelenik meg a nemi szere- 
peknek megfelelő magatartás helyeslése. Ennek a jelenségnek az oka talán az lehet, hogy ma már kevésbé elfogadott a nemekkel kapcsolatos elöítéletek nyílt hangoztatása (Plant és Devine, 1998). A szereplő viselkedéséről való nemi sztereotípiák által átitatott vélemény kimondása túl nyílt megnyilvánulási forma lenne, a főnök viselkedésének megítélésével sokkal rejtettebb formában közvetítheti a nemekkel kapcsolatos nézeteit a személy.

A kutatásunknak ugyanakkor vannak korlátai. Vizsgálatunkban csak egyféle viselkedés jelent meg, a segítés, és a kutatásban nem manipuláltuk a segítés különböző formáit, illetve más szervezeti viselkedéseket sem vontunk be a vizsgálatba. További aggályként merülhet fel, hogy nem végeztünk az embereknek az adott szituációban megjelenő segítéssel kapcsolatos reprezentációira vonatkozóan előzetes felméréseket. Természetesnek vettük, hogy az általunk vázolt helyzetben illik segíteni, és nem vettük figyelembe az ezzel kapcsolatos, akár eltérő észleleteket. Kutatásunk további korlátját jelenti, hogy adottnak vettük a banki kultúra versengő/maszkulin, az iskolai kultúra támogató/feminin jellegét, ugyanakkor erre vonatkozóan nincsenek szakirodalmi utalások. A vizsgálati személyeink különböző munkahelyi háttérrel rendelkeztek, így érdemes lett volna a válaszadók munkahelyének szervezeti kultúráját is felmérni. Vizsgálatunk további hiányosságaként említhető a férfi vizsgálati személyek alacsony száma: a kérdőív verzióinak nagy száma miatt az egyes feltételekbe kevés férfi válaszadó jutott, így a megfigyelt tendenciák alapvetően a nőkre jellemzőek. A jövőben mindenképpen érdemes lenne tehát kibővíteni a mintánkat további férfiak válaszaival.

\section{MELLÉKLETEK}

1. melléklet. A kérdőívben használt munkahelyi szituáció (dőlt betűvel az egyes feltételekben változó részekkel)

A következőkben egy munkahelyi szituációt olvashat, arra kérem, hogy képzelje bele magát az egyik szereplő, Ágnes helyébe!

Ágnes (Gábor) egy iskolában (bankban) dolgozik, ahol nemrég egy új adminisztrációs rendszert vezettek be. A rendszer használatáról már korábban tartottak egy képzést, amelyen mindenkinek, aki ezt a rendszert használja a munkája során, részt kellett venni. Egyik nap munka közben Ágnest az egyik kollégája megkereste, hogy magyarázza el neki az új adminisztrációs rendszer használatát. Ugyan ez a munkatárs is részt vett a képzésen, de családi gondjai miatt nem tudott rendesen odafigyelni, és nagyon szégyelli a dolgot, de a rendszer használata nélkül nem tud haladni a munkájával, ezért kérte Ágnes (Gábor) segítségét.

Bár Ágnesnek/Gábornak rengeteg munkája van és a rendszer használatának elmagyarázása is sok idöt vesz igénybe, mégis úgy döntött, hogy segít kollégájának./Ágnesnek (Gábornak) rengeteg munkája van és a rendszer használatának elmagyarázása is sok idóbe telne, ráadásul mások is részt vettek a képzésen, ezért úgy döntött, hogy most nem segít kollégájának, és azt javasolta neki, hogy kérjen meg valaki mást. 
Ennek az esetnek a híre eljutott Ágnes (Gábor) közvetlen feletteséhez is, aki örömmel állapittotta meg, hogy elrendezödött a probléma laki Ágnes (Gábor) segítségét egy plusz szabadnappal jutalmazta meg laki nemtetszését fejezte ki, és figyelmeztette Ágnest (Gábort), hogy ha ez még egyszer elöfordul, akkor annak már következményei lesznek.

\section{2. melléklet. A szereplő viselkedésének megítélésére vonatkozó állítások}

1. Ágnesnek (Gábornak) segítenie kellett./Ágnesnek (Gábornak) segítenie kellett volna.

2. Ágnes (Gábor) a helyzetnek megfelelően járt el.

3. Ágnes (Gábor) az adott helyzetben helytelenül járt el.

\section{3. melléklet. A főnök viselkedésének megítélésére vonatkozó állítások}

1. A főnök reakciója helyénvaló volt.

2. A főnök az adott helyzetnek megfelelően járt el.

3. A főnök fair módon járt el.

\section{IRODALOM}

Allen, T. D. (2006). Rewarding good citizens: The relationship between citizenship behavior, gender, and organizational rewards. Journal of Applied Social Psychology, 36(1), 120143.

Catanzaro, D., Moore, H., \& Marshall, T. R. (2010). The impact of organizational culture on attraction and recruitment of job applicants. Journal of Business and Psychology, 25(4), 649-662.

Colquitt, J. A., Conlon, D. E., Wesson, M. J., Porter, C. O. L. H. \& NG, K. Y. (2001). Justive at the Millenium: A meta-analytic review of 25 years of organizational justice research. Journal of Applied Psychology, 86(3), 425-445.

Davison, H. K., \& Burke, M. J. (2000). Sex discrimination in simulated employment contexts: A meta-analytic investigation. Journal of Vocational Behavior, 56(2), 225-248.

Deaux, K., \& EMswiller, T. (1974). Explanations of successful performance on sex-linked tasks: What is skill for the male is luck for the female. Journal of Personality and Social Psychology, 29(1), 80-85.

DiON, K. L. (1975). Women's reactions to discrimination from members of the same or opposite sex. Journal of Research in Personality, 9(4), 294-306.

Dipboye, R. L., Arvey, R. D., \& Terpstra, D. E. (1977). Sex and physical attractiveness of raters and applicants as determinants of resume evaluations. Journal of Applied Psychology, 62(3), 288-294.

Fernandez, M. L., Castro, Y. R., \& Lorenzo, M. G. (2004). Evolution of hostile sexism and benevolent sexism in a Spanish sample. Social Indicators Research, 66(3), 197-211. 
Gaucher, D., Friesen, J., \& Kay, A. C. (2011). Evidence that gendered wording in job advertisements exists and sustains gender inequality. Journal of Personality and Social Psychology, 101(1), 109-128.

GLICK, P., \& Fiske, S. T. (1996). The ambivalent sexism inventory: Differentiating hostile and benevolent sexism. Journal of Personality and Social Psychology, 70(3), 491-512.

GLICK, P., \& FISKE, S. T. (1997). Hostile and benevolent sexism. Measuring ambivalent Sexist attitudes toward women. Psychology of Women Quarterly, 21(1), 119-135.

GLICK, P., \& Fiske, S. T. (2006). Ambivalens szövetség - Az ellenséges és jóindulatú szexizmus mint a nemi egyenlőtlenség egymást kiegészítő igazolásai. In D. L. Hamilton, S. T. Fiske, \& J. A. BARGH [válogatta és szerkesztette: HunYADY GY.], A társak és a társadalom megismerése (389-447). Budapest: Osiris.

Heilman, M. E. (2001). Description and prescription: How gender stereotypes prevent women's ascent up the organizational ladder. Journal of Social Issues, 57(4), 657-674.

Heilman, M. E. (2012). Gender stereotypes and workplace bias. Research in Organizational Behavior, 32, 113-135.

Heilman, M. E., \& Chen, J. J. (2005). Same behavior, different consequences: Reactions to men's and women's altruistic citizenship behavior. Journal of Applied Psychology, 90(3), 431-441.

Heilman, M. E., \& Guzzo, R. A. (1978). The perceived cause of work success as a mediator of sex discrimination in organizations. Organizational Behavior and Human Performance, 21(3), 346-357.

Hoffman, C., \& Hurst, N. (1990). Gender stereotypes: Perception or rationalization? Journal of Personality and Social Psychology, 58(2), 197-208.

Johnson, S. K., Holladay, C. L. \& QuinOnes, M. A. (2009). Organizational citizenship behavior in performance evaluations: Distributive justice or injustice? Journal of Business and Psychology, 24(4), 409-418.

Jost, J. T., Pelham, B. W., \& Carvallo, M. R. (2002). Non-conscious forms of system justification: Implicit and behavioral preferences for higher status groups. Journal of Experimental Social Psychology, 38(6), 586-602.

Kidder, D. L., \& MCLeAn PARKs, J. (2001). The good soldier: Who is s(he)? Journal of Organizational Behavior, 22(8), 939-959.

KovÁcs J. (2014). Az igazságosság és a hatékonyság az interperszonális és a társadalmi kapcsolatok pszichológiájában. Debrecen: Debreceni Egyetemi Kiadó.

MAiER, M. (1999). On the gendered substructure of organization: Dimensions and dilemmas of corporate masculinity. In G. N. Powell (Ed.), Handbook of Gender \& Work (6994). Thousand Oaks, CA: Sage Publications.

Neumark, D., \& MCLennan, M. (1995). Sex discrimination and women's labor market outcomes. The Journal of Human Resources, 30(4), 713-740.

NGuYen, L. L. A. (2005). Férfiak és nők a munka világában. Nemi szerepek a munkahelyen. Magyar Pszichológiai Szemle, 60(1), 111-134.

Plant, E. A., \& Devine, P. G. (1998). Internal and external motivation to respond without prejudice. Journal of Personality and Social Psychology, 75(3), 811-832.

Prentice, D. A., \& CARranza, E. (2002). What women and men should be, shouldn't be, are allowed to be, and don't have to be: The contents of perspective gender stereotypes. Psychology of Women Quarterly, 26(4), 269-281.

PRYOR, J. B. (1995). The psychosocial impact of sexual harassment on women in the U.S. military. Basic and Applied Social Psychology, 17(4), 581-603. 
Russel, B. L., \& TrigG, K. Y. (2004). Tolerance of sexual harassment: An examination of gender differences, ambivalent sexism, social dominance, and gender roles. Sex Roles, $50(7 / 8), 565-573$.

SCHEIn, E. H. (1984). Coming to a new awareness of organizational culture. Sloan Management Review, 25(2), 3-16.

Schmitt, M. T., Branscombe, N. R., \& Postmes, T. (2003). Women's emotional responses to the pervasiveness of gender discrimination. European Journal of Social Psychology, 33(3), 297-312.

SOMECH, A., \& Drach-ZAHAVy, A. (2004). Exploring organizational citizenship behaviour from an organizational perspective: The relationship between organizational learning and organizational citizenship behaviour. Journal of Occupational and Organizational Psychology, 77(3), 281-298.

Veiga, J., Lubatkin, M., Calori, R., \& Very, P. (2000). Measuring organizational culture clashes: A two-nation post-hoc analysis of a cultural compatibility index. Human Relations, 53(4), 539-557.

\title{
PERCEIVED FAIRNESS OF GENDER ROLE CONSERVING AND ASSESSING BEHAVIOR OF THE LEADER PENDING ON THE ORGANIZATIONAL CULTURE AND THE PERCEIVER'S SEXIST ATTITUDE
}

\author{
DALLOS, ANDREA - KOVÁCS, JUDIT
}

The present study investigates the perceived fairness of helping which appearance or absence is accordant or discordant with gender role expectations and our research also examines the perceived justice of the leader's reaction to this behavior. The actor's gender, the appearance of helping and the leader's given reaction (neutral or rewarding/punishing) were manipulated, but the possible influencing effects of organizational culture and the respondent's level of sexism was also tested.

Our questionnaire was filled in by 310 women and 65 men. The respondents read a short description of a workplace situation in which we manipulated the previously named factors. After reading this situation participants indicated the perceived fairness of the actor's and the leader's behavior and the ambivalent sexism scale were filled in.

According to our results the participants judged the helping behavior as more appropriate than the failure to help and this judgment was not influenced by the independent factors. Among respondents who were in the competitive/masculine culture and neutral leader-response condition and who had high levels of sexism, the leader's neutral response was perceived as more fair in the case of the male actor than in the case of the female actor, in this way the gender role conserving behavior of the leader was accepted. Nevertheless when the leader responded with reward or punishment, the respondents who read about the supporting/feminine organizational culture or who were non-sexist regarded the gender role inverting reaction of the leader as more just: the approval of rewarding the female actor and punishing the male actor emerged.

Key words: $\quad$ gender roles, gender role expectations, helping, fairness, sexism 